Бабій Ю. О., к.т.н.; Поліщук В. В.

Національна академія Державної прикордонної служби України імені Богдана Хмельницького, Хмельницький

\title{
Класифікація та перспективи розвитку технічних засобів охорони та захисту кордону
}

Резюме: За результатами аналізу встановлена суттєва недостатність технічних засобів охорони кордону, які забезпечують автоматичне виявлення рухомих об'єктів та гарантують реалізацію принципу неперервності у часі охорони сухопутного кордону. Визначені та узагальнені вимоги до засобів моніторингу рухомих об'єктів на протяжних ділянках сухопутного кордону.

Ключові слова: рухомий об'єкт, моніторинг державного кордону, сухопутний кордон, технічні засоби охорони кордону, технічні засоби захисту кордону, радіотехнічний комплекс моніторингу.

Постановка проблеми. Понад двох десятків найменувань технічних засобів охорони (ТЗО) кордону застосовувались у минулому в прикордонних військах для виявлення правопорушників (ПП).На сьогодні такий перелік дещо зменшився i, в основному, стосується тепловізорів і оптико-електронних приладів. Звичайно, широка номенклатура засобів не є критерієм забезпечення ефективного посилення охорони кордону.

Аналіз останніх досліджень i публікацій. У публікації [1] відзначається, що на сьогодні ймовірність великомасштабних воєн невелика, при цьому, зростає загроза розв'язання локальних воєн і військових конфліктів із використанням звичайних засобів збройної боротьби. У цих умовах особливу важливість набувають сучасні види озброєння і військової техніки, в тому числі засоби захисту та охорони державного кордону, що і виявило потребу в їх класифікації, визначенні та узагальненні вимог на протяжних ділянках сухопутного кордону.

Метою статті $\epsilon$ визначення та узагальнення загальних вимог до засобів моніторингу рухомих об'єктів на протяжних ділянках сухопутного кордону.

Виклад основного матеріалу. Завдяки порівнянню світового ринку технічних засобів, які можна розглядати як потенційні технічні засоби захисту та охорони державного кордону (ТЗЗОДК) з прийнятими ними класифікаціями в Державній прикордонній службі України (ДПСУ), встановлено невідповідність між:

1) потребою в логічному та структурованому представленні переліку типів технічних засобів для охорони та захисту i практично відсутність їх загальної класифікаційної моделі;

2) наявними типами технічних засобів захисту та охорони і відсутністю окремих типів в діючій системі класифікації ТЗО кордону;
3) віднесенням ТЗ3 до класу ТЗО кордону та необхідністю виділення їх в окремий клас технічних засобів;

4) потребою в однозначності назв окремих типів технічних засобів, стандартизації ïx y різних галузях та неоднозначністю в концептуальному апараті по ТЗО кордону.

На сьогодні щодо першого пункту, загальна класифікаційна модель (структура ТЗО границі) відсутня. По суті, відповідно до керівних документів [2, 3] ТЗО кордону діляться на радіолокаційно-прожекторні, сигналізаційні, оптичні та оптико-електронні. У зазначених класах ТЗО здійснюється розподіл за ступенем мобільності, протяжності охорони, що є тільки вершиною ієрархії класифікаційної моделі множини ТЗО.

Щодо другої невідповідності, то, наприклад, відсутній клас засобів підповерхневої локації типу георадарів. Однак такі засоби успішно застосовуються в ДПСУ 3 2014 року. Очевидно, що за наявною адекватною класифікацією ТЗО, ці засоби, які понад десятиліття застосовуються в інших галузях, могли б бути набагато раніше використані в ДПСУ. Це б не дало змоги перерости в окремих випадках, наприклад, прокладання тунелів, трубопроводів через державний кордон, у порівняно нову загрозу національній безпеці, породжену саме в прикордонній, але наявній у військовій, соціальній, економічній сферах. Так само, застосування тактичних безпілотних літальних апаратів (БПЛА) в охороні кордону логічно розглядати 3 позиції експлуатації ТЗО, а не як вид авіаційного засобу. Але їх відрізняє лише носій ТЗО, а експлуатація та іiі організація фактично $\epsilon$ складовою інженерно-технічного забезпечення. Особливо така невідповідність може загостритися при застосуванні БПЛА за викликом, за даними первинного виявлення ПП 
засобами охорони. Тому, невеликі тактичні БПЛА можна розглядати як клас ТЗО.

Щодо третьої невідповідності, то, наприклад, застосування в прикордонних військах раніше електрошокових засобів ИЕ200, ГИ-1 реалізовувались комплексно з ТЗО, до яких вони відносяться, проте, призначення електрошокових засобів - це захист кордону. Нині такі засоби швидко розвиваються, в основному вони називаються засобами нелетального впливу, а їх клас все більше розширюється [4].

Причини недосконалості класифікації ТЗЗОЗДК слід шукати не тільки в бурхливому розвитку радіоелектроніки в охоронній зоні, але i у невизначеності концептуального пристрою оперативно-господарської діяльності ДПСУ щодо таких функцій як охорона та захист кордону. Така невизначеність загострилася 3 початком агресії в південній та східній частині країни.

Відзначимо, що охорона переходить до захисту, коли локально ПП починає застосовувати силу та зброю.

Стосовно технічного аспекту, по суті, ТЗО виявляють ПП, а ТЗ3 впливають фізично на ПП, ускладнюють пересування на рівні 3 інженерними загородженнями. Прогнозувалося, що саме Т3З кордону набудуть у перспективі пріоритету у застосуванні, не вимагаючи виявлення ПП та подальшого його затримання, якщо ПП рухається до нас і змінює свої наміри через вплив засобів захисту кордону. Тобто, процес охорони кордону 3 обов'язковим виявленням, спостереженням та затримкою ПП може перетворитися на процес захисту кордону 3 нелетальним впливом і спостереженням за зоною впливу. При цьому, істотним $\epsilon$ те, що будуть відсутні дорогі, складні, високочутливі технічні засоби для виявлення ПП.

Щодо четвертої невідповідності, то, наприклад, згідно 3 різними державними стандартами, сигналізаційні комплекси відносяться до засобів охорони периметра, територіально-розподілених радіотехнічних систем охорони i ТЗО протяжних ділянок кордону $[5,6]$. Тому, логічно запропонувати назву для всього спектра технічних засобів, які можуть застосовуватися для посилення охорони та захисту кордону ТЗЗОДК [6], до яких віднесено всі технічні засоби, що посилюють охорону та захист державного кордону.

Також виділено в окремий підклас комплексні технічні засоби захисту та охорони кордону, що забезпечують одночасно і виявлення, і ускладнення пересування ПП.

Досвід бойових дій визначили потребу у розвитку засобів охорони, що забезпечують охорону позицій, блокпостів. По суті, це сигналізаційні засоби охорони локальних ділянок кордону, але останні, через недосконалість класифікації, а, відповідно, i відсутність вимог до окремих характеристик, не забезпечують необхідних функцій охорони зазначених об' єктів.

Порівняно новими технічними засобами спостереження (ТЗС) $є$ сейсмолокаційні та акустичні засоби, георадари. Iз зазначених засобів, сейсмолокаційні $\epsilon$ універсальними, оскільки забезпечують виявлення та визначення місця розташування рухомого об' єкта в повітрі, на землі та під землею, що робить цей клас ТЗС перспективним у виявленні не тільки людей i автотранспорту, але й визначення місця розташування зброї, що здійснює постріли, визначення руху об'єктів у грунті, хоча на сьогодні для виявлення підповерхневих комунікацій ефективно застосовують тільки георадари.

Однією 3 нових небезпек є проліт БПЛА і як датчик виявлення таких ПП, очевидно, доцільно застосовувати радіолокаційні та акустичні ТЗС у складі сигналізаційних засобів охорони протяжних ділянок кордону, а саме, в складі сигналізаційних комплексів.

Такі засоби, як прожекторні станції світлотехнічних засобів, остаточно будуть у перспективі витіснені через застосування тепловізорів.

Для охорони ділянок кордону перспективним є застосування електричних мін, що забезпечують нелетальний вплив через покрокову напругу.

Усі перераховані невідповідності виявили потребу у визначенні та узагальненні вимог до засобів моніторингу рухомих об'єктів (РО) на протяжних ділянках сухопутного кордону.

Загальні вимоги до засобів моніторингу РО на сухопутному кордоні Украӥни.

Призначення: автоматичне виявлення, визначення дальності до РО, напрямку переміщення (від нас, до нас) візуальне спостереження в межах рубежу основних інженерних споруд, розпізнавання ПП.

Склад засобу: радіоелектронний комплекс iз лінійною i станційною частинами. Лінійна частини включає датчик або датчики, відеокамери 3 нічною підсвіткою, розподілені вздовж флангів охорони, з'єднанні кабелем живлення і передачі даних. Станційна - ПЕОМ оператора, апаратура вводу/виводу даних і блок живлення. У перспективі до складу комплексу мають входити засоби нелетального впливу, ураження безпілотних РО.

Тактико-технічні вимоги: 20 км;

- протяжність флангу охорони - не менше

- кількість флангів - 2; час напрацювання на хибну тривогу при обслуговуванні одним оператором i відсутності можливості 
відеотепловізійного розпізнавання ПП - не менше 720 годин;

- час напрацювання на хибну тривогу при обслуговуванні одним оператором i наявності можливості відеотепловізійного розпізнавання ПП - не менше 1 години;

- РО, які виявляються - людина, транспорт, БПЛА, підземні комунікації;

- похибка визначення дальності - до 10 м;

- висота встановлення відеокамери 3 постійним відеоспостереженням - 2-3 м;

- дальність виявлення БПЛА - до 3 км;

- глибина виявлення підземних комунікацій - до 10 м.

Вимоги до функиіонування засобу: лінійна частина розміщується вздовж лівого і правого флангів ділянки охорони кордону на огорожі, на стовпах або приховано. Відеокамери 3 постійною зоною спостереження, 3 інфрачервоною підсвіткою, встановлюються на залізобетонних стовпах, висотою 2-3 м. У центрі ділянки охорони розміщується підрозділ охорони зі станційною частиною. Після автоматичного виявлення РО, визначається дальність i напрямок переміщення РО. Вмикається у темний час доби інфрачервона підсвітка і здійснюється спостереження за РО у межах POІC. Розпізнається ПП, у тому числі, на закритій, пересіченій місцевості. У перспективі зазначене стосується як наземних РО, так i БПЛА та підземних комунікацій. Також, за наявності засобів впливу здійснюється нелетальний вплив на людей $\mathrm{i}$ можливе знешкодження БПЛА.

Загальні вимоги до моніторингу РО на позиції спостереження.

Призначення: автоматичне виявлення, розпізнавання, визначення сектора знаходження PO. інші).

Склад засобу: прилад (сейсмічний або

Тактико-технічні вимоги:

- автоматичне виявлення РО на відстані не менше 30 м;

- визначення сектора однозначного місцезнаходження РО - не більше 45 град.;

- час напрацювання на хибну тривогу - не менше 1 години; не реагування на сигнали від РО, що переміщується в радіусі 3-4 м.

Вимоги до функціонування засобу: після автоматичного виявлення РО, що наближається до приладу, розпізнається ПП, визначається сектор місцезнаходження РО. Прилад не повинен демаскувати позицію спостереження, не повинен реагувати на переміщення РО поруч 3 ним. Встановлення приладу має бути безпосередньо на позиції, поруч зі спостерігачем.
Загальні вимоги до засобу моніторингу РО на локальних ділянках сухопутного кордону.

Призначення: автоматичне виявлення, визначення дальності до РО, напрямку переміщення (від нас, до нас).

Склад засобу: прилад 3 лінійною частиною. Лінійна частини включає розподілений чутливий елемент (ЧЕ).

Тактико-технічні вимоги:

- протяжність ділянки охорони - не менше 2 км;

- похибка визначення дальності - до 10 м;

- час напрацювання на хибну тривогу при обслуговуванні одним оператором і відсутності можливості відеотепловізійного розпізнавання ПП - не менше 720 годин;

- час напрацювання на хибну тривогу при обслуговуванні одним оператором і наявності можливості відеотепловізійного розпізнавання ПП - не менше 1 год.

Вимоги до функиіонування засобу: ЧЕ лінійної частини розміщується вздовж ділянки охорони кордону або по периметру об'єкта охорони, або на огорожі. Після автоматичного виявлення РО, визначається дальність і напрямок переміщення РО. ЧЕ має бути малопомітним і забезпечувати функціонування, у тому числі, на закритій, пересіченій місцевості.

Загальні вимоги до засобу моніторингу БПЛА вздовж державного кордону.

Призначення: автоматичне виявлення, розпізнавання, визначення дальності, висоти, курсу, швидкості польоту.

Склад засобу: лінійна і станційна частина. Лінійна включає датчики (радіолокаційні або інші), з'єднані кабелем живлення і передачі даних. Станційна - ПЕОМ оператора, апаратура вводу/виводу даних і блок живлення.

Тактико-технічні вимоги: 20 км;

протяжність флангу охорони - не менше

кількість флангів - 2;

PO, які виявляються - БПЛА з розмахом крила більше 2 м і ЕВП $<0,1 \mathrm{~m}^{2}$;

висота виявлення цілей - до 3 км; похибка визначення курсу польоту цілі -

до 15 град;

похибка визначення дальності - до 30 м; похибка визначення швидкості польоту цілі - до 30 км/год;

радіолокаційні (або інші) датчики дистанційно керовані, 3 електронним скануванням променю, встановлених на залізобетонних стовпах, висотою 2-3 м.

Вимоги до функиіонування засобу: датчики лінійної частини розміщуються вздовж лівого i правого флангів ділянки охорони кордону, закріплюються на стовпах і не повинні 
мати рухомих механічних антен. У центрі ділянки охорони розміщується підрозділ охорони зі станційною частиною. Після автоматичного виявлення РО у повітрі, розпізнається БПЛА, визначаються координати, принаймні у двох точках супроводження БПЛА, визначається курс польоту, швидкість, висота.

Висновки. У статті проведено аналіз укомплектованості технічними засобами охорони для здійснення моніторингу сухопутного кордону. Результатом аналізу $\epsilon$ встановлення суттєво недостатнього забезпечення підрозділів ТЗО кордону, які забезпечують автоматичне виявлення РО та гарантують реалізацію принципу неперервності у часі охорони сухопутного кордону. Розглянуті основні положення концепції моніторингу дали змогу сформувати загальні вимоги до засобів моніторингу РО на сухопутному кордоні України.

\section{СПИСОК ВИКОРИСТАНОЇ ЛІТЕРАТУРИ}

1. Сніцаренко П. М. Теорія озброєння. Науковотехнічні проблеми та завдання: монографія: Технічні засоби. Військові системи дистанційного моніторингу навколишнього простору щодо рухомих об'єктів: методологічні аспекти обгрунтування вимог / П. М. Сніцаренко, С. В. Лапицький, А. А. Гультяєв, О.О.Головін, А. Ю. Гупало. - К : Видавничий дім Дмитра Бураго, 2016. - 480 с.

2. Наказ №544 АДПСУ від 11.07.2005p. "Про затвердження i введення в дію Настанови 3 експлуатації радіолокаційно-прожекторного озброєння у Державній прикордонній службі України".

3. Наказ №809 Адміністрації ДПСУ від 05.11.2004p. "Про затвердження та введення в дію Інструкції про визначення термінів експлуатації інженерних споруд, норм напрацювання до ремонту та списання технічних засобів охорони кордону, інженерної техніки та майна у Державній прикордонній службі України".

4. Козлов С. Обзор технических средств активного противодействия вторжениям на объекты различной категории / С. Козлов, Д. Львов. $-\mathrm{M}$ : БДИ. - 2009 - № 3-4 - С. 30-35.

5. ДСТУ 4000-2000. Системи тривожної сигналізації. Охоронні теле(відео)системи і системи контролювання доступу.

6. ДСТУ 3960-2000. Системи тривожної сигналізації. Системи охоронної і охороннопожежної сигналізації. Терміни та визначення.

Стаття надійшла до редакції 30.10.2017

Бабий Ю. А., к.т.Н.;

Полищук В. В.

Национальная академия Государственной пограничной службы Украины имени Богдана Хмельницкого, Хмельницкий

\section{Классификация и перспективы развития технических средств охраны и защиты границы}

Резюме: По результатам анализа установлена существенная недостаточность технических средств охраны границы, которые обеспечивают автоматическое обнаружение движущихся объектов и гарантируют реализацию принципа непрерывности во времени охраны сухопутной границы. Определены и обобщены требования к средствам мониторинга подвижных объектов на протяженных участках сухопутной границы.

Ключевые слова: движущийся объект, мониторинг государственной границы, сухопутная граница, технические средства охраны границы, технические средства защиты границы, радиотехнический комплекс мониторинга.

\section{Y. Babiy, Ph.D;}

V. Polishchuk

National academy of the State Border Guard Service of Ukraine, Khmelnitsky

Classification and prospects of the development of technical means of protection and protection of the border

Resume. According to the results of the analysis, there is a significant lack of technical means of border protection that provide automatic detection of moving objects and guarantee the implementation of the principle of continuity in time protection of the land border. Requirements for monitoring of mobile objects on extended sections of the land border have been defined and summarized.

Keywords: moving object, monitoring of the state border, land border, technical means of border guard, technical means of border protection, radio monitoring complex. 